Anita Rodina, Dr. iur.

University of Latvia, Latvia

\title{
SUSTAINABILITY AS THE STATE PRINCIPLE, DIVERSITY OF ITS APPLICATION IN PRACTICE
}

\begin{abstract}
Summary
In the article, the author analyses the principle of subsidiarity, which can be described as part of a broad social strategy. Without denying that this principle originated in or was created under the influence of environmental law, currently sustainability has been given a broader scope and it demands long-term thinking in different areas.

The author points out that the principle of sustainability is not solely a political or governmental principle. It is included in normative acts expressis verbis in specific areas, turning into a principle of a certain field. Moreover, the principle of sustainability has become a constitutional principle. In the Preamble of the Satversme (constitution), the concept of sustainable development and responsibility towards future generations are included.

The author proves that Latvia belongs to the countries which recognize global environmental constitutionalism with sustainability as one of its elements. Furthermore, analyses confirm that the principle of sustainability is applied both by the Constitutional Court and the courts belonging to the court system in different areas.

By analysing the concept "sustainability constitutionalism", the author discloses the content of sustainable legal regulation.
\end{abstract}

Keywords: sustainability, Constitution [Satversme], Constitutional Court, constitutionalism, legislation

\section{Introduction}

Currently, nobody doubts that one of the major future challenges for mankind will be the issues related to ecosystems and environment, protection and safeguarding of it. Awareness of the environment's importance has led to development of several principles, which, over time, have surpassed the environmental law and have become paramount principles of national development. Sustainability is one of these principles.

Sustainability is a new term in legal science. However, sustainability is one of those principles that have undergone extensive development, in particular, recently: it has both international and national dimension; it is used by the legislator, as well as politicians; sustainability is extensively applied in the case law in various areas. This is why the principle of sustainability has become an overall guiding principle for human development and achieving sustainability has become the central issue 
of our time. ${ }^{1}$ Today, it is indeed impossible to treat sustainability as an isolated "environmental goal" - it is a part of a broad social strategy. ${ }^{2}$

This article aims to present the meaning of the sustainability principle in Latvia in both policy and law documents, to reveal the application of this principle in diverse areas, proving that the phenomenon, which is globally known as sustainability constitutionalism, can also be discussed in the context of Latvia.

\section{The roots and content of sustainability. Some general remarks}

Usually, the roots or the origin of the term or legal concept of sustainability are related to 1987 when the World Commission on Environment and Development (known as Brundtland Commission ${ }^{3}$ ) published the statement "Our common future". However, sustainability is a concept with much deeper roots. Sources reveal that the idea of sustainable development was expressed already in 1713 when Hanns Carl von Carlowitz edited the first book on forest sciences ${ }^{4}$ pointing to the need for caution, a balance between timber growth and lumbering. At that time, however, a precise definition of the sustainability principle was not provided. However, this conclusion comprised the idea of sustainability. It has been also noted that sustainability had been known sooner - in countries of medieval western Europe in agriculture - land cultivation, and also in forestry. ${ }^{5}$ A push towards awareness of this concept was given also in 1798 by Tomas Malthus in his "Essay on the Principle of Population". His thesis was that population increases geometrically, while food increases arithmetically. ${ }^{6}$ However, 1987 is the time when this concept gains recognition within the international community. It is known that it was the Brundtland Commission's report that served as the push towards more detailed discussions of the problems that later evolved in 1992 in Rio de Janeiro Earth Summit. ${ }^{7}$ Following that, "Agenda $21^{\text {" }}$ was issued as a guide for countries

1 John A. Vucetich and Michael P. Nelson. Sustainability: Virtuous or Vulgar? BioScience, Vol. 60, No. 7, July/August 2010, p. 539.

2 Farber, D. A. Law, Sustainability, and the Pursuit of Happiness. UC Berkeley: Berkeley Program in Law and Economics. Available at: https://escholarship.org/uc/item/6289107q [last viewed October 4, 2019].

3 Commission Chair was Gro Harlem Brundtland, the former Minister of Norway.

4 Keiner M. History, Definition(s) and Models of “Sustainable Development”. Available at: https:// www.research-collection.ethz.ch/bitstream/handle/20.500.11850/53025/1/eth-27943-01.pdf [last viewed October 4, 2019].

5 Warde P. Modern Intellectual History, No. 8, Issue 1, 2011, pp. 153-163.

6 Malthus T. R. Essay on the Principle of Population. Electric Book Company, 2000. ProQuest Ebook Central. Available at: https://ebookcentral.proquest.com/lib/lulv/detail.action?docID=3008464 [last viewed July 7, 2019].

7 Portney K. Sustainability. Cambridge: The MIT Press, 2015, p. 32.

8 United Nations Conference on Environment \& Development Rio de Janerio, Brazil, 3 to 14 June 1992 AGENDA 21. Available at: https://sustainabledevelopment.un.org/content/documents/ Agenda21.pdf [last viewed July 20, 2019]. 
with respect to the economic development on the $21^{\text {st }}$ century. The Sustainable Development Goals of the United Nations were defined in 2015, to be achieved by 2030. ${ }^{9}$

Various explanations of sustainability can be found in sources of law. For example, is has been mentioned that "sustainable development means ensuring dignified living conditions with regard to human rights by creating and maintaining the widest possible range of options for freely defining life plans." ${ }^{10}$ Likewise, it has been noted that the core meaning of sustainability has been the preservation of natural systems supporting human life. ${ }^{11}$ The so-called Brundtland Commission's principle of sustainability was defined as "development that meets the needs of the present without compromising the ability of future generations to meet their own needs" ${ }^{12}$ This is the most frequently used definition of sustainability worldwide as well as in Latvia. This understanding of sustainability is used also by the Constitutional Court of the Republic of Latvia in its case law. ${ }^{13}$ Sustainability has been explained also in the normative regulation. Section 1 of the Environmental Protection Law points out that the principle of sustainable development should be regarded as the integrated and balanced development of public welfare, the environment and economy, which meets the present social and economic needs of inhabitants and ensures the compliance with environmental requirements, not endangering the possibility to meet the needs of the future generations, as well as ensures the preservation of biologic diversity. ${ }^{14}$

9 Sustainable Development Goals. Available at: https://www.un.org/sustainabledevelopment/ sustainable-development-goals/ [last viewed July 7, 2019].

10 Keiner M. History, Definition(s) and Models of "Sustainable Development". Available at: https:// www.research-collection.ethz.ch/bitstream/handle/20.500.11850/53025/1/eth-27943-01.pdf [last viewed July 7, 2019].

11 Bosselmann K. Global Environmental Constitutionalism: Mapping the Terrain. Widener Law Review, Vol. 21, No. 2, pp. 180-181. Available at: http://datubazes.lanet.lv:2095/login.aspx?direct= true $\& \mathrm{db}=\mathrm{a} 9 \mathrm{~h} \& \mathrm{AN}=110507334 \&$ site $=$ ehost-live [last viewed July 16, 2019].

12 Report of the World Commission on Environment and Development: Our Common Future Available at: https://www.are.admin.ch/are/en/home/sustainable-development/internationalcooperation/2030agenda/un- -milestones-in-sustainable-development/1987--brundtland-report. html [last viewed July 7, 2019].

13 See, for example, Judgement of the Constitutional Court of the Republic of Latvia of 24 February 2011 in case No. 2010-48-03, para. 6.1. Available at: http://www.satv.tiesa.gov.lv/web/viewer. $\mathrm{html}$ ?file=/wp-content/uploads/2010/07/2010-48-03_Spriedums_ENG.pdf\#search=2010-48-03 [last viewed July 16, 2019]; Judgement of the Constitutional Court of the Republic of Latvia of 17 January 2008 in case No. 2007-11-03, para 15. Available at: http://www.satv.tiesa.gov.lv/web/viewer. html?file=/wp-content/uploads/2007/05/2007-11-03_Spriedums_ENG.pdf\#search=2007-11-03 [last viewed October 10, 2019].

14 Environmental Protection Law. Available at: http://www.vvc.gov.lv/export/sites/default/docs/ LRTA/Likumi/Environmental_Protection_Law.doc [last viewed July 16, 2019]. 
Usually, three dimensions or three pillars of sustainability are discerned: environmental ${ }^{15}$, economic ${ }^{16}$, and social ${ }^{17}$. In other sources, the social dimension is replaced by equity. ${ }^{18}$ The idea of sustainability is that all the three elements should go hand in hand.

Sustainability is not a principle applicable solely in public law. It reaches beyond, as it is applicable also in private law - in business. For example, sustainability indicators are sought and identified in the private sector. ${ }^{19}$ The terms "sustainability of business activities ${ }^{20}$ " or "sustainable activities of the personnel" are known, used in Section 8 the Enterprise Income Tax Law. ${ }^{21}$ Sustainability criteria are applied in the area of biofuels and bioliquids. ${ }^{22}$

Thus, it can be said that sustainability has broad dimensions and is being applied in diverse areas. Without denying that this principle originated in or was created under the influence of environmental law, currently sustainability has been given a broader scope. Likewise, the essence of sustainability is found in two key elements: the need to satisfy the humanity's present needs, at the same time caring for the future generations in various fields. To put it differently - the sustainability principle demands long-term thinking.

\section{Sustainability as an element of development in Latvia: political and legal aspects}

It has been noted in research that the actual efforts and politics of nation states to promote sustainability differ greatly. ${ }^{23}$ This is because sustainability, first of all, is a political issue. Sustainability as a political standard was underscored by President E. Levits upon coming into office, highlighting the common good, responsibility for the future generations, which is a style of thinking typical of a modern and

15 Environmental sustainability speaks about preserving and protecting ecosystem and natural sources

16 Sustainable development (economy) highlights the principle that economical activities should avoid depleting natural resources and damaging ecosystems.

17 Social or equity tools for more equitable distribution of environmental impacts, natural resources, good, service, income and wealth.

18 Portney K. Sustainability. Cambridge: The MIT Press, 2015, p. 7.

19 See more: Swedbank's Sustainability Indicators: towards the 2030 Agenda. Available at: https://www.swedbank-research.com/english/macro_focus/2018/january/sustainability indicators 2018-01-23.pdf [last viewed July 16, 2019].

20 Judgement of Administrative Regional Court of 26 April 2018 in case No. A420296416 para. 3. 27. Available at: https://manas.tiesas.lv/eTiesasMvc/nolemumi [last viewed October 4, 2019 ].

21 Corporate Income Tax Law. Latvijas Vēstnesis, No. 56 (5983), 08.08.2017.

22 Regulations of the Cabinet of Ministers No. 545 of 5 July 2011. Sustainability criteria for biofuels and bioliquids, their implementation mechanism and monitoring and control mechanisms. Latvijas Vèstnesis, No. 111 (4509), 19.07.2011.

23 Portney K. Sustainability. Cambridge: The MIT Press, 2015, p. 141. 
sustainable state. ${ }^{24}$ The finding that solidarity, belonging to Latvia and to Europe, the possibility to live in a modern state is the basis for the will for a sustainable state points to the purpose of the state - to be sustainable. ${ }^{25}$

The "road map" for the development of Latvia is based on political document "National Development Plan of Latvia for 2014-2020", which was approved by the Saeima (parliament). ${ }^{26}$ In addition to this document, the parliament has approved also the Sustainable Development Strategy of Latvia until 2030 or "Latvia 2030". It aims to reach sustainable development of a country, i.e., an integrated and balanced development of the public welfare, the environment and economics, which satisfies the present social and economic needs of inhabitants, ensures the observation of the environmental requirements, without endangering the possibility to satisfy the needs of future generations, and ensuring the biological diversity. "Latvia 2030" is the main national planning instrument, which means that all other policy planning documents must comply with the guidelines defined in this legal act. The content of sustainability is presented in this document, comprising the general understanding of the concept in Latvia and reflecting, first of all, the three globally known dimensions of sustainability and the need to find a balance between them (public welfare, environment, economics), and, secondly, it links the interests of the present and the future society and discusses the need to balance these.

In Latvia, the principle of sustainability is not solely a political or governmental principle. This principle is included in normative acts expressis verbis in specific areas, turning into a principle of a certain field. Moreover, the principle of sustainability has become a constitutional principle.

Latvia is one of those rare countries, where, almost 100 years after its constitution was adopted, an extensive Preamble was added to the Satversme in $2014 .^{28}$ The Preamble to the Satversme comprises, inter alia, the following phrases: "Each individual takes care of [..] future generations, the environment and nature" and "Latvia protects its national interests and promotes sustainable and democratic development of a united Europe and the world."29 The conclusion that follows from the Preamble is, first of all, that sustainability has become one of the principles for national development. To foster sustainable Europe and the world, Latvia itself must be oriented towards such development. Secondly, the constitutional legislator expects also responsible actions from each individual for the sake of future

${ }^{24}$ Speech by President Egils Levits at the Saeima upon entering office. Available at: https:// www.president.lv/lv/jaunumi/zinas/valsts-prezidenta-egila-levita-runa-saeima-amatastajoties-25796 [last viewed October 5, 2019].

25 Ibid.

26 National Development Plan of Latvia for 2014-2020. Available at: https://www.pkc.gov.lv/sites/ default/files/inline-files/NDP2020\%20English\%20Final 1.pdf [last viewed October 5, 2019].

27 Sustainable Development Strategy of Latvia until 2030. Available at: http://varam.gov.lv/lat/pol/ $\mathrm{ppd} /$ ?doc=13857, para. 8. [last viewed October 10, 2019].

28 Amendments to the Constitution of the Republic of Latvia. Latvijas Vèstnesis, No. 131 (5191), 08.07.2014.

29 The Constitution of the Republic of Latvia. Available at: http://saeima.lv/en/about-saeima/workof-the-saeima/constitution/ [last viewed October 5, 2019]. 
generations, which is also an integral part of sustainability. Moreover, it is noted in a study of the preambles of different states that usually preambles include norms belonging to three groups: 1) those that reflect the constitutional foundations of the state, 2) matters related to fundamental human rights, and 3) the elements of national nature that are characteristic of the particular country. ${ }^{30}$ The author believes that sustainability does not fall within any of these groups typical of preambles' texts. Sustainability should be recognised as being a new - a future principle of national development, which has been differently reflected expressis verbis in constitutions of various states.

It has been noted that nearly 20 countries expressly recognize a constitutional goal of "sustainability" or "sustainable development". ${ }^{31}$ For example, the Constitution of Switzerland notes that the aim of the Federation (Article 2) is to promote common welfare, sustainable development, inner cohesion, and cultural diversity of the country. ${ }^{32}$ This principle is reflected in the Preamble to the Constitution of Montenegro. ${ }^{33}$ This concept is also included in constitutions of Poland, Mozambique, Greece, Serbia, and Thailand. ${ }^{34}$ Other constitutions refer to the concept of "future generations". For example, Article 110B of the Constitution of the Kingdom of Norway states that "Natural resources should be made use of on the basis of comprehensive long-term considerations whereby this right will be safeguarded for future generations as well." ${ }^{5}$ The concept of protecting future generations is included in several constitutions, e.g., in Germany and Brazil, and those norms mainly speak about preserving natural resources and environment and responsibility to the future generation. ${ }^{36} \mathrm{~A}$ study mentions that in some countries constitutions include both: sustainability and also the future generation concept (Angola, Bhutan, Georgia, Guyana, Malawi, Maldives, Sweden). ${ }^{37}$ Latvia belongs to the latter group

30 Constitutional Preambles. A comparative analysis. Voermans W., Stremler M., Cliteur P. (eds.), Chaltenham: Edward Elgar Publishing: 2017, p. 25.

31 James R. May Sustainability and Global Environmental Constitutionalism. In: New Frontiers in Environmental Constitutionalism. Available at: https://wedocs.unep.org/bitstream/handle/ 20.500.11822/20819/Frontiers-Environmental-Constitutionalism.pdf? sequence =1\&isAllowed=y [last viewed October 10, 2019], p. 310.

32 Federal Constitution of the Swiss Confederation of April 18, 1999. Available at: https://www. refworld.org/docid/3ae6b6040.html [last viewed October 7, 2019].

33 Constitution of Montenegro. Available at: https://www.wipo.int/edocs/lexdocs/laws/en/me/ me004en.pdf [last viewed October 7, 2019].

34 James R. May Sustainability and Global Environmental Constitutionalism. In: New Frontiers in Environmental Constitutionalism. Available at: https://wedocs.unep.org/bitstream/handle/ 20.500.11822/20819/Frontiers-Environmental-Constitutionalism.pdf? sequence $=1$ \&isAllowed $=y$ [last viewed October 7, 2019], pp. 312-313.

35 Constitution of the Kingdom of Norway of 1814. Available at: https://ihl-databases.icrc.org/ihlnat/6fa4d35e5e3025394125673e00508143/eee956c813a2da0ec1256a870049de0c/\%24FILE/ Constitution.pdf [last viewed October 7, 2019].

36 James R. May Sustainability and Global Environmental Constitutionalism. In: New Frontiers in Environmental Constitutionalism. Available at: https://wedocs.unep.org/bitstream/handle/ 20.500.11822/20819/Frontiers-Environmental-Constitutionalism.pdf? sequence =1\&isAllowed=y [last viewed October 7, 2019], pp. 313-314.

37 Ibid., pp. 314-315. 
of countries, as the constitution contains the sustainable development concept and responsibility towards future generations.

Although the principle of sustainability is included in the Preamble to the Satversme, it is a directly applicable principle. The Latvian theory of constitutional law does not doubt that all norms of the Satversme that have been included in the whole text of the Satversme are real and applicable. ${ }^{38}$ Therefore, sustainability is one of the constitutional principles aimed at protecting and implementing the aims and values enshrined in the Satversme. ${ }^{39}$ One might also say that sustainability has become a principle that will take a more prominent place alongside principles like democracy, a country governed by the rule of law, and human dignity.

\section{Application of sustainability principle in case law: diversity of areas and practice}

It would be wrong to assume that, in Latvia, the principle of sustainability has been applied only since the Preamble to the Satversme was adopted and entered into force. The Constitutional Court had applied this principle on several occasions before that, because the sustainability principle has been defined in special laws, for example, in the Environmental Protection Law since it came into force in 2006.

The study of case law shows that the principle of sustainability is applied both by the Constitutional Court and the courts belonging to the court system, and that in the case law the sustainability principle had been applied in very diverse areas, for example, even terms "sustainability of a judgement" been used. At the same time, it must be noted that the contribution by the European Court of Human Rights to sustainable development has been assessed as being small. ${ }^{42}$ Therefore, embodiment of the sustainability principle in Latvia depends, first and foremost, on courts: the Constitutional Court and courts of the court system, which have been called upon to care for the protection of normative acts and the Satversme.

In view of the origins and development of sustainability, it is clear that initially the sustainability principle was applied in the environmental law. Although at present it has acquired new horizons, the diversity of its application in environmental

38 Pleps J. Satversmes ievada piemērošana [Application of the Preamble of Satversme]. Jurista vārds, No. 30 (832), 5.08.2014.

39 Judgement of the Constitutional Court of the Republic of Latvia of 6 October 2016 in case No. 2016-24-03, para. 11. Latvijas Vèstnesis, No. 201, 10.10.2017.

40 Judgement of Riga Regional Court of 23 November 2016 in case No. C30692915. Available at: https://manas.tiesas.lv/eTiesasMvc/nolemumi [last viewed October 10, 2019].

${ }^{41}$ Judgement of regional Administrative Court on 14 June 2018 in case No. A420511213. Available at: https://manas.tiesas.lv/eTiesasMvc/nolemumi [last viewed October 11, 2019].

42 Verschuuren, J. Contribution of the case law of the European Court of Human Rights to sustainable development in Europe. In: W. Scholtz, \& J. Verschuuren (eds.), Regional Environmental Law: Transregional Comparative Lessons in Pursuit of Sustainable Development. Cheltenham: Edward Elgar Publishing Ltd, 2015, p. 15. 
law is obvious also in Latvia. Thus, for example, similarly to other European countries $^{43}$, also in Latvia, sustainability is one of the principles of spatial planning. ${ }^{44}$ The Constitutional Court of Latvia even describes the principle of sustainability as "one of the fundamental principles of land use planning". ${ }^{45}$ As the Constitutional Court has been vigorously involved in solving legal issues connected to spatial planning, the Constitutional Court has developed some rules on the application of this principle or provided some guidelines to users. ${ }^{46}$

Alongside environmental law, the sustainability principle is being actively applied in social law. For example, since Latvia has recognised itself as being a socially responsible state, it has been derived from this principle that it is the duty of the state to form a sustainable and balanced policy for ensuring the welfare of the society. ${ }^{47}$ It has been recognised in the case law of the Constitutional Court that Article 109 of the Satversme guarantees the inhabitants the right to a stable and predictable, as well as effective, just and sustainable system of social protection, which ensures commensurate social services. ${ }^{48}$ Also, it has been explained that the sustainability of the system means that it should be of the kind that would allow ensuring social

43 Vincent Hély, Jean-Philippe Antoni. Combining indicators for decision making in planning issues: A theoretical approach to perform sustainability assessment. Sustainable Cities and Society, Vol. 44, 2019, p. 844.

44 Spatial Planning Law says that in the development of a spatial plan the principle of sustainability, which ensures a qualitative environment, balanced economic development, rational utilisation of natural, human and material resources, development and preservation of the natural and cultural heritage for the present and next generations, should be observed. Spatial Planning Law. Available at: http://www.vvc.gov.lv/export/sites/default/docs/LRTA/Likumi/Spatial_Planning_Law.doc [last viewed October 1, 2019].

45 Judgement of the Constitutional Court of the Republic of Latvia of 17 January 2008 in case No. 2007-11-03, para. 15. Available at: http://www.satv.tiesa.gov.lv/web/viewer.html?file=/wpcontent/uploads/2007/05/2007-11-03_Spriedums_ENG.pdf\#search=2007-11-03 [last viewed October 10, 2019].

46 Judgement of the Constitutional Court of the Republic of Latvia of 24 September 2008 in case No. 2008-03-03, para. 17.2. Latvijas Vèstnesis, No. 151 (3935), 30.09.2008; Judgement of the Constitutional Court of the Republic of Latvia of 30 January 2004 in case No. 2003-20-01, para. 8.2. Available at: http://www.satv.tiesa.gov.lv/web/viewer.html?file=/wp-content/uploads/ 2003/09/2003-20-01_Spriedums_ENG.pdf\#search=2003-20-01 [last viewed October 11, 2019]; Judgement of the Constitutional Court of the Republic of Latvia of 3 May 2011 in case No. 2010-54-03, para. 12.1.1. Latvijas Vēstnesis, No. 70 (4468), 06.05.2011. Judgement of the Constitutional Court of the Republic of Latvia of 9 October 2014 in case No. Nr.2013-19-03, para. 15.1. Latvijas Vèstnesis, No. 201 (5261), 10.10.2014.; Judgement of the Constitutional Court of the Republic of Latvia of 19 November 2009 in case No. 2009-09-03, para. 14. Latvijas Véstnesis, No. 184 (4170), 24.11.2009.

47 Judgement of the Constitutional Court of the Republic of Latvia of 15 March 2010 in case No. 2009-44-01, para. 22. Available at: http://www.satv.tiesa.gov.lv/web/viewer.html?file=/wpcontent/uploads/2009/07/2009-44-01_Spriedums_ENG.pdf\#search=2009-44-01 [last viewed October 11, 2019].

48 Judgement of the Constitutional Court of the Republic of Latvia of 19 December 2011 in case No. 2011-03-01, para. 15.2. Available at: http://www.satv.tiesa.gov.lv/web/viewer.html?file=/wpcontent/uploads/2011/02/2011-03-01_Spriedums_ENG.pdf\#search=2011-03-01 [last viewed October 11, 2019]. 
security not only to the present but also to the future generations. ${ }^{49}$ This means that the legislator should always be able to balance and use reasonably the state budget resources, weighing the rights of an individual and the welfare of the whole society. ${ }^{50}$ I.e., the state's actions should never jeopardise the sustainability of the social budget. ${ }^{51}$ Ensuring the sustainability of the social budget has been deemed to be a legitimate aim for restricting fundamental rights in the case law of the Supreme Court. ${ }^{52}$ With respect to the pension system, it has been found that the sustainability of pension system is based on three principles: adequacy, financial sustainability and capability to adapt itself to changes. ${ }^{53}$

Sustainability also has been recognised as an essential principle in the regulation of the system of higher education. ${ }^{54}$ Recently, this principle has gained a new dimension in the case law of the Constitutional Court, which has applied the sustainability principle to various institutions of constitutional law (see further).

\section{Some remarks about global constitutionalism, global environmental constitutionalism and sustainability}

Presently, a new concept - global constitutionalism - has emerged. ${ }^{55}$ As noted by professor Klaus Bosselmann, the phenomenon of global constitutionalism is created by the growing interdependence of nation states, which has generated a certain "constitutionalization of international organizations" recognizing such principles as human rights, state responsibility, and ius cogens or erga omnes norms. ${ }^{56}$ I.e., values, which usually have been examined in a national framework (for example, the rule of law, justice, human rights), today are addressed more comprehensively

49 Judgement of the Constitutional Court of the Republic of Latvia of 15 February 2018 in case No. 2017-09-01, para. 15.1. Latvijas Vēstnesis, No. 35 (6121), 19.02.2018.

50 Judgement of the Constitutional Court of the Republic of Latvia of 19 October 2017 in case No. 2016-14-01, para. 19.3. Latvijas Vēstnesis, No. 209 (6036), 20.10.2017.

51 Judgement of the Constitutional Court of the Republic of Latvia of 15 February 2018 in case No. 2017-09-01, para. 15.1. Latvijas Vèstnesis, No. 35 (6121), 19.02.2018.

52 Judgement of the Supreme Court of the Republic of Latvia on 14 December 2015 in case No. A420445113 para. 5. Available at: https://manas.tiesas.lv/eTiesasMvc/nolemumi [last viewed October 10, 2019]; Judgement of the Supreme Court of the Republic of Latvia on 2 October 2014 in case No. A420401913, para. 4.6. Available at: https://manas.tiesas.lv/eTiesasMvc/nolemumi [last viewed October 10, 2019].

53 Judgement of the Constitutional Court of the Republic of Latvia of 21 December 2009 in case No. 2009-43-01, para. 27.2. Available at: http://www.satv.tiesa.gov.lv/web/viewer.html?file=/wpcontent/uploads/2009/07/2009-43-01_Spriedums_ENG.pdf\#search=2009-43-01 [last viewed October 10, 2019].

54 Judgement of the Constitutional Court of the Republic of Latvia of 7 June 2019 in case No. 201815-01, para. 18. Latvijas Vèstnesis, No. 116, 10.06.2019.

55 See more about constitutionalism in World Constitutionalism, Principal V. M. et al. (eds.), Cambridge Scholars Publisher, 2007, pp. 1-16.

56 Bosselmann K. Global Environmental Constitutionalism: Mapping the Terrain. Widener Law Review, Vol. 21, No. 2, p. 171. Available at: http://datubazes.lanet.lv:2095/login.aspx?direct=true\& $\mathrm{db}=\mathrm{a} 9 \mathrm{~h} \& \mathrm{AN}=110507334 \&$ site=ehost-live [last viewed July 16, 2019]. 
due to their global nature. This principle is known in Latvia because, for example, the harmony of the national fundamental human rights and international human rights is recognised ${ }^{57}$ Human rights as the most important aspect of contemporary constitutionalism are relevant in all countries. It could be said that Latvia is integrated in this global chain of constitutionalism.

Today, protection of the environment is of fundamental importance. The Constitutional Court has upheld this finding. ${ }^{58}$ One can subscribe to professor $\mathrm{K}$. Bosselmann's thesis - if environmental protection has constitutional status in many states and if "we accept that the twenty-first century will be defined by its success or failure of protecting human rights and the environment" ${ }^{\prime 9}$ then it is possible to talk about global environmental constitutionalism. Environmental constitutionalism concerns not only the duty to realize environmental obligations but also the procedure in which those obligations should be fulfilled. ${ }^{60}$ Sustainability is one of the principles of environmental constitutionalism. ${ }^{61}$ It can be said that, in Latvia, lots of attention is paid to the development, implementation and effectiveness of environmental rights in the constitution, because, first of all, the Satversme includes Article $115^{62}$, and the obligation of institutions of public power is derived thereof to establish and maintain an effective system for environmental protection; and, secondly, as noted above, the concept of sustainability, environmental protection has been enshrined expressis verbis in the Preamble to the Satversme. Thus, it can be said that Latvia successfully fits into global environmental constitutionalism with sustainability as one of its elements.

57 Judgement of the Constitutional Court of the Republic of Latvia of 21 December 2009 in case No. 2009-43-01, para. 20. Available at: http://www.satv.tiesa.gov.lv/web/viewer.html?file=/wpcontent/uploads/2009/07/2009-43-01_Spriedums_ENG.pdf\#search=2009-43-01 [last viewed July 16, 2019].

58 Judgement of the Constitutional Court of the Republic of Latvia of 24 February 2011 in case No. 2010-48-03, para. 6. Available at: http://www.satv.tiesa.gov.lv/web/viewer.html?file=/wpcontent/uploads/2010/07/2010-48-03_Spriedums_ENG.pdf\#search=2010-48-03 [last viewed July 16, 2019].

59 Bosselmann K. Global Environmental Constitutionalism: Mapping the Terrain. Widener Law Review, Vol. 21, No. 2, p. 173. Available at: http://datubazes.lanet.lv:2095/login.aspx?direct=true\& $\mathrm{db}=\mathrm{a} 9 \mathrm{~h} \& \mathrm{AN}=110507334 \&$ site $=$ ehost-live [last viewed July 16, 2019].

60 Kotzé L. J. Arguing Global Environmental Constitutionalism. Transnational Environmental Law, Vol. 1, No. 1, 2012, p. 208.

${ }_{61}$ Prof. Kotze notes that that environmental constitutionalism includes several elements, like, environmental rights; environmental justice; intra- and intergenerational equity; ecological integrity; sustainability and its associated principles (functioning here as universal environmental moral and ethical ideals or values); an extended vision of the environmental obligations of the state and the private sector; judicial control of executive and legislative environmental governance functions; and an expansive notion of private and public accountability. Kotzé, L. J. Arguing Global Environmental Constitutionalism. Transnational Environmental Law, Vol. 1, No. 1, 2012, p. 209.

62 Article 115 of the Constitution states that "The State shall protect the right of everyone to live in a benevolent environment by providing information about environmental conditions and by promoting the preservation and improvement of the environment." 


\section{Sustainability and the duty of individuals}

Clearly, the primary responsibility for preserving environment in the context of sustainability principle lies with the state and those institutions that have various obligations that follow from Article 115 and other normative acts. The thesis that the possibilities of the current and the future generations to live in a wholesome environment in many ways depend on the state's readiness to ensure sustainable development should be upheld..$^{63}$ Moreover, the responsibility of the state should be understood broadly and it cannot be attributed only to performing the function of sanctioning. The state's obligation to preserve and improve environmental quality, to use sustainable natural resources should be discussed. However, at the same time, it is important to understand also the responsibility of each individual - each member of society - for implementing the sustainability principle. Hence, in the context of the sustainability principle, also the principle of personal responsibility should be discussed. Everyone's responsibility follows from the third sentence in the fifth paragraph of the Preamble to the Satversme, which provides that everyone should care for, among others, future generations, environment and nature, thus imposing an obligation on all to become involved in the implementation of sustainability. This does not concern only the environmental protection. Responsibility to the future generations means responsible actions in various areas of life. In other words, sustainability is not solely the state's responsibility. Each and every member of society should care for the implementation of this principle.

In view of everyone's duty in the context of sustainability, the matter regarding agricultural land, which is one of the most important natural resources for the national economy in Latvia has been dealt with in the case law. ${ }^{64}$ The Constitutional Court, referring to the sustainability principle included in the Preamble to the Satversme, including everyone's duty and responsibility to the next generations and environment, has defined the obligations of the owners of agricultural land, inter alia, to ensure preservation, effective use and tilling of agricultural land, which includes preservation of biological diversity typical of Latvia, as well as to care for the use, cultivation of such land and to preserve it for future generations. ${ }^{65}$ It can be said that case law recognises the principle of personal responsibility in the context of sustainability.

\footnotetext{
${ }^{63}$ Judgement of the Constitutional Court of the Republic of Latvia of 6 October 2016 in case No. 2016-24-03, para. 7. Latvijas Vèstnesis, No. 201, 10.10.2017.

${ }^{64}$ Judgement of the Constitutional Court of the Republic of Latvia of 18 October 2018 in case No. 2018-04-01, para. 16. Latvijas Vēstnesis, No. 208 (6294), 22.10.2018.

65 Ibid.
} 


\section{Sustainability and constitutionalism. Sustainability in the Latvian constitutional law}

The concept of "sustainability constitutionalism", which incorporates both values - constitutionalism and sustainability, is known in legal science. ${ }^{66}$ This concept can be used in various ways. It can be taken as the basis for making new normative acts and also applied in state law. Analysis of case law shows that in Latvia, in the field of constitutional law, sustainability has been applied in various ways. For example, it has been recognised in case law that national sustainability means the state's responsibility for adopting a sustainable budget ${ }^{67}$, which is always linked to the obligation to ensure the existence of appropriate resources in the state budget. ${ }^{68}$ Sustainability is linked also to democracy and respect for human rights and fundamental freedoms, which are interconnected and mutually reinforcing values. ${ }^{69}$ The concept of "sustainability of democracy" has become enshrined in case law. It is understood as the need to care for the protection of the national constitutional bodies and national security institutions against persons, who by their actions pose a threat to the independence of the State of Latvia and to the principles of a democratic state governed by the rule of law. ${ }^{70}$

In the case law of the Constitutional Court over the last years findings have crystallised that are attributed to the legislator and the policy it implements, by adopting generally binding legal norms in the context of developing a sustainable state. Since the legislator has been called to exercise the legislative power, the outcomes of its work and also the procedure should be oriented towards a sustainable result. It can be said that sustainable development is closely linked to the existence of sustainable legal regulation. ${ }^{71}$ Thus, two main aspects have crystallised: the sustainability of the state and sustainable legal regulation as one element of a sustainable state.

The author believes that a sustainable legal regulation, first and foremost, complies with the Satversme, both as to its content and form, or in the process of

66 James R. May Sustainability and Global Environmental Constitutionalism. In: New Frontiers in Environmental Constitutionalism. Available at: https://wedocs.unep.org/bitstream/handle/ 20.500.11822/20819/Frontiers-Environmental-Constitutionalism.pdf? sequence=1\&isAllowed=y [last viewed October 7, 2019], p. 315.

67 Judgement of the Constitutional Court of the Republic of Latvia of 3 February 2012 in case No. 2011-11-0, para. 17.5. Available at: http://www.satv.tiesa.gov.lv/web/viewer.html?file=/wpcontent/uploads/2011/05/2011-11-01_Spriedums_ENG.pdf\#search=2011-11-01 [last viewed October 8, 2019].

68 Judgement of the Constitutional Court of the Republic of Latvia of 25 March 2015 in case No. 2014-11-0103, para. 20. Available at: http://www.satv.tiesa.gov.lv/web/viewer.html?file=/ wp-content/uploads/2014/04/2014-11-0103_Spriedums_ENG.pdf\#search=2014-11-0103 [last viewed October 8, 2019].

69 Judgement of the Constitutional Court of the Republic of Latvia of 29 June 2018 in case No. 2017-25-01, para. 20.2. Latvijas Vèstnesis, No. 130 (6216), 02.07.2018.

70 Ibid., Judgement of Regional Administrative Court of 30 August 2018 in the case No. A43007918. Available at: https://manas.tiesas.lv/eTiesasMvc/nolemumi [last viewed October 5, 2019 ].

71 Judgement of the Constitutional Court of the Republic of Latvia of 18 April 2019 in case No. 2018-16-03, para. 17. Latvijas Vèstnesis, No. 80 (6419), 23.04.2019. 
its adoption the norms and principles of the Satversme have been complied with. It has been found in the case law of the Constitutional Court that the sustainability principle is applicable also to the legislative process and thus, sustainability can be attained by implementing also the principle of good legislation that is derived from the principle of a state governed by the rule of law. ${ }^{72}$ Likewise, the principle of a sustainable state requires a legislative outcome that is well-considered, is not hurried and is stable. In the context of the principle of legal security ${ }^{73}$, the legal norms adopted by the legislator, in addition to being predictable and clear must also be stable and constant, allowing a person to make not only short-term decisions but also to build the long-term future plans. ${ }^{74}$ The case law of the Constitutional Court recognises a solution as being sustainable if it, for example, in a particular field - electricity production - will facilitate "sustainable and safe production of electricity". ${ }^{5}$ In hearing the so-called case of "Solidarity Tax - Natural Persons", the Constitutional Court found that, notwithstanding the legislator's discretion in the area of taxation policy, it had to abide by the principles of effectiveness, fairness, solidarity, and timeliness. ${ }^{76}$ Although these principles have been applied to the normative regulation in a narrow field - taxation, the author believes that, obviously, these principles, taking into account the specificity of each particular area, may be applied to any sustainable normative solution. Any legal regulation should be just. The principle of justice is always the main leitmotif of a state governed by the rule of law. The opinion can be upheld that justice can be attained if harmony and balance are ensured; the principle of equality is abided by; the distribution of benefits is merit-based. ${ }^{77}$ The whole legislative process should be aimed at attaining justice. Obviously, normative regulation should be effective, which includes economic effectiveness. Alongside the economic effectiveness, another standard for measuring the effectiveness of the law exists. ${ }^{78}$ It has been explained that the effectiveness of a law is determined by the fact whether society and courts abide by the particular law. ${ }^{79}$ Likewise, timeliness is not of a minor importance also in other areas, not only in that of taxation.

Timeliness means that new normative regulation is introduced in a wellconsidered way and timely manner. Hurried, ill-considered, constantly amended laws do not create and develop society's trust in public power. ${ }^{80} \mathrm{~A}$ law, which is amended already in the year following its adoption, cannot be deemed to be sustainable. President of the State R. Vejonis also has pointed to this problem, concluding that the outcome of an ill-considered legal regulation is the need to improve and amend it. ${ }^{81}$ However, the legislator should strive for constantly growing trust of persons in the state and law, as well as increasing awareness of the democratic process. This is an element of the principle of a rule-of-law state - to ensure stable laws in the state that

79 Falcón y Tella M. J. Justice and Law. Leiden: BRILL, 2014, p. 26.

${ }^{80}$ Van der Meer T. In what we trust? A multi-level study into trust in parliament as an evaluation of state characteristics. International Review of Administrative Sciences, Vol. 3, No. 76, 2010, p. 518.

81 Valsts prezidenta 2019. gada 4. februāra vēstule Nr. 36 Saeimas Juridiskajai komisijai [Letter of the State President of 4 February 2019 to Saeima Legal Committee]. Available at: https://www. president.lv/storage/kcfinder/files/VP_040219_Nr.36.pdf [last viewed July 12, 2019]. 
determine human lives. ${ }^{82}$ Laws that are constantly amended do not create a stable legal environment. Likewise, the laws, in the adoption of which substantial and procedural violations have been committed, cannot promote and ensure sustainable national development. Sustainable normative regulation cannot be aimed at ensuring benefit to a particular person. It must serve society. Therefore, also in case law, sustainable solution is oriented towards protection of public welfare. ${ }^{83}$

The legislator's actions always should be aimed at a sustainable solution, and not only formally so. The legislator's aim should always be the adoption of good law - one that fosters trust in the state and law. ${ }^{84}$ The legislator should always keep in mind that law influences the future, not the past. ${ }^{85}$ This conclusion appositely fits into the context of sustainability.

\section{Conclusions}

1. Although sustainability is a new term in legal science, it has become the guiding principle for human development and the central issue for states.

2. Although the sustainability principle originated in environment law, it has acquired broad dimensions and is being applied in the most diverse areas, retaining the essence of sustainability: the need to satisfy the present needs of humanity, at the same time taking care of the future generations. To phrase it differently - the sustainability principle demands long-term thinking.

3. In Latvia, the sustainability principle is not solely a political or governmental principle. This principle is included in normative acts expressis verbis in specific areas, turning it into a principle of a specific area. Moreover, the principle of sustainability has become a constitutional principle aimed at protection and implementation of aims and values included in the Satversme.

4. A conclusion follows from the Preamble to the Satversme that sustainability has become one of the principles of national development. To promote sustainable Europe and the world, Latvia itself should be oriented towards such development.

5. The research of the case law shows that the sustainability principle is applied both by the Constitutional Court and the courts belonging to the court system, and in the case law the sustainability principle has been applied in very diverse areas - environmental law and legal institutions related to it, in social law, in the area of higher education, and in state law. The case law of the recent years outlines the following trend: 1) the sustainability principle is constantly being

82 Lautenbach G. The Concept of the Rule of Law and the European Court of Human Rights. Oxford: Oxford University Press, 2013, p. 21.

83 Judgement of the Constitutional Court of the Republic of Latvia of 18 October 2018 in case No. 2018-04-01, para. 16. Latvijas Vēstnesis, No. 208 (6294), 22.10.2018.

84 Dissenting opinion of the Justice of the Constitutional Court of the Republic of Latvia Daiga Rezevska in case No. 2016-14-01, para. 6. Latvijas Vèstnesis, No. 251 (6078), 18.12.2017.

85 Driesen D. M. The Economic Dynamics of Law, Cambridge University Press, 2012, p. 1. 
applied in new branches of law; 2) the significance of sustainability pronouncedly dominates in the rulings by Constitutional Court and also the courts belonging to the court system created in the recent years.

6. Latvia successfully fits into the global environmental constitutionalism, one element of which is sustainability.

7. Sustainability is not solely the state's responsibility. The constitutional legislator expects responsible actions from each individual for the sake of the next generations, which is an integral part of sustainability.

8. Since the legislator has been called to exercise the legislative power, the outcomes of its work and also the procedure should be oriented towards a sustainable result. It can be said that sustainable development is closely linked to the existence of sustainable legal regulation. Thus, two main aspects have crystallised: the sustainability of the state and sustainable legal regulation as one element of a sustainable state.

9. Sustainable legal regulation, first and foremost, complies with the Satversme, both as to its content and form, and in the process of its adoption the norms and principles of the Satversme have been complied with, inter alia, the principles of effectiveness, justice, solidarity and timeliness, it is well-considered and dependable regulation.

\section{BIBLIOGRAPHY}

\section{Literature}

1. Bosselmann K. Global Environmental Constitutionalism: Mapping the Terrain. Widener Law Review, Vol. 21, No. 2. Available at: http://datubazes.lanet.lv:2095/login.aspx?direct=true\& $\mathrm{db}=\mathrm{a} 9 \mathrm{~h} \& \mathrm{AN}=110507334 \&$ site $=$ ehost-live [last viewed July 16, 2019].

2. Driesen D. M. The Economic Dynamics of Law. Cambridge: Cambridge University Press, 2012.

3. Falcón y Tella M. J. Justice and Law. Leiden: BRILL, 2014.

4. Farber D. A. Law, Sustainability, and the Pursuit of Happiness. UC Berkeley: Berkeley Program in Law and Economics. Available at: https://escholarship.org/uc/item/6289107q [last viewed October 4, 2019].

5. Hély V., Antoni J. P. Combining indicators for decision making in planning issues: A theoretical approach to perform sustainability assessment. Sustainable Cities and Society, Vol. 44, 2019.

6. James R. May Sustainability and Global Environmental Constitutionalism. In: New Frontiers in Environmental Constitutionalism. Available at: https://wedocs.unep.org/ bitstream/handle/20.500.11822/20819/Frontiers-Environmental-Constitutionalism. pdf? sequence $=1 \&$ isAllowed $=y$, [last viewed October 10, 2019].

7. Keiner M. History, Definition(s) and Models of "Sustainable Development". Available at: https://www.research-collection.ethz.ch/bitstream/handle/20.500.11850/53025/1/eth27943-01.pdf [last viewed October 4, 2019].

8. Kotzé L. J. Arguing Global Environmental Constitutionalism. Transnational Environmental Law, Vol. 1, No. 1, 2012. 
9. Lautenbach G. The Concept of the Rule of Law and the European Court of Human Rights. Oxford: Oxford University Press, 2013, p. 21.

10. Levits E. Speech by President Egils Levits at the Saeima on taking office. Available at: https://www.president.lv/lv/jaunumi/zinas/valsts-prezidenta-egila-levita-runa-saeimaamata-stajoties-25796 [last viewed October 5, 2019].

11. Malthus T. R. Essay on the Principle of Population, Electric Book Company, 2000. ProQuest Ebook Central. Available at: https://ebookcentral.proquest.com/lib/lulv/detail. action? docID=3008464 [last viewed July 7, 2019].

12. Pleps J. Satversmes ievada piemērošana [Application of the Preamble of Satversme]. Jurista vārds, No. 30 (832), 2014.

13. Portney K. Sustainability. Cambridge: The MIT Press, 2015.

14. Principal V. M. et al. World Constitutionalism. Cambridge: Cambridge Scholars Publisher, 2007.

15. Rezevska D. Tiesiskās drošības un tiesiskās paḷāvības principi - būtiski tiesiskas valsts principa elementi. [The principles of legal certainty and the protection of legitimate expectations as essential elements of the rule of law] In: Vispārējie tiesību principi: tiesiskā drošība un tiesiskā palāiviba [General principles of law: legal certainty and the protection of legitimate expectations]. Valsts pārvalde. Bizness. Jurisprudence. Rīga: Tiesu namu aǵentūra, 2017.

16. Shavell S. Foundations of Economic Analysis of Law. Cambridge, Mass: Harvard University Press, 2004.

17. Van der Meer T. In what we trust? A multi-level study into trust in parliament as an evaluation of state characteristics. International Review of Administrative Sciences, Vol. 3, No. 76, 2010.

18. Verschuuren J. Contribution of the case law of the European Court of Human Rights to sustainable development in Europe. In: Scholtz W., \& Verschuuren J. (eds.), Regional Environmental Law: Transregional Comparative Lessons in Pursuit of Sustainable Development. Cheltenham: Edward Elgar Publishing Ltd., 2015.

19. Vējonis R. Valsts prezidenta 2019. gada 4. februāra vēstule Nr. 36 Saeimas Juridiskajai komisijai [Letter of the State President No. 36 of 4 February 2019 to Saeima Legal Committee]. Available at: https://www.president.lv/storage/kcfinder/files/VP_040219_Nr.36.pdf [last viewed July 12, 2019].

20. Vucetich J. A. and Nelson M. P. Sustainability: Virtuous or Vulgar? BioScience, Vol. 60, No. 7, 2010, p. 539.

21. Voermans W., Stremler M., Cliteur P. Constitutional Preambles. A comparative analysis. Chaltenham: Edward Elgar Publishing, 2017, p. 25.

22. Warde P. Modern Intellectual History, No. 8, issue 1, 2011, pp.153-163.

\section{Legislative acts}

1. The Constitution of the Republic of Latvia. Available at: http://saeima.lv/en/about-saeima/ work-of-the-saeima/constitution/ [last viewed October 5, 2019].

2. Amendments to the Constitution of the Republic of Latvia. Latvijas Vēstnesis, No. 131 (5191), 08.07.2014.

3. Constitution of Montenegro. Available at: https://www.wipo.int/edocs/lexdocs/laws/en/ me/me004en.pdf [last viewed October 7, 2019]. 
4. Constitution of the Kingdom of Norway of 1814. Available at: https://ihl-databases.icrc.org/ ihl-nat/6fa4d35e5e3025394125673e00508143/eee956c813a2da0ec1256a870049de0c/\%24 FILE/Constitution.pdf [last viewed October 7, 2019].

5. Federal Constitution of the Swiss Confederation of April 18, 1999. Available at: https://www. refworld.org/docid/3ae6b6040.html [last viewed October 7, 2019].

6. Environmental Protection Law. Available at: http://www.vvc.gov.lv/export/sites/default/ docs/LRTA/Likumi/Environmental_Protection_Law.doc [last viewed July 16, 2019].

7. Corporate income tax law. Latvijas Vēstnesis, No. 56 (5983), 08.08.2017.

8. Spatial Planning Law. Available at: http://www.vvc.gov.lv/export/sites/default/docs/LRTA/ Likumi/Spatial_Planning_Law.doc [last viewed October 1, 2019].

9. Regulation of the Cabinet of Ministers No 545 of 5 July 2011. Sustainability criteria for biofuels and bioliquids, their implementation mechanism and monitoring and control mechanisms. Latvijas Vēstnesis, No. 111 (4509), 19.07.2011.

\section{Legal practice}

1. Judgement of the Constitutional Court of the Republic of Latvia of 7 June 2019 in case No. 2018-15-01, para. 18. Latvijas Vèstnesis, No. 116, 10.06.2019.

2. Judgement of the Constitutional Court of the Republic of Latvia of 18 April 2019 in case No. 2018-16-03. Latvijas Vēstnesis, No. 80 (6419), 23.04.2019.

3. Judgement of the Constitutional Court of the Republic of Latvia of 6 March 2019. in case No. 2018-11-01. Latvijas Vēstnesis, No. 48 (6387), 08.03.2019.

4. Judgement of the Constitutional Court of the Republic of Latvia of 18 October 2018 in case No. 2018-04-01. Latvijas Vēstnesis, No. 208 (6294), 22.10.2018.

5. Judgement of the Constitutional Court of the Republic of Latvia of 29 June 2018 in case No. 2017-25-01. Latvijas Vēstnesis, No. 130 (6216), 02.07.2018.

6. Judgement of the Constitutional Court of the Republic of Latvia of 15 February 2018 in case No. 2017-09-01. Latvijas Vēstnesis, No. 35 (6121), 19.02.2018.

7. Judgement of the Constitutional Court of the Republic of Latvia of 19 October 2017 in case No. 2016-14-01. Latvijas Vēstnesis, No. 209 (6036), 20.10.2017.

8. Judgement of the Constitutional Court of the Republic of Latvia of 6 October 2016 in case No. 2016-24-03. Latvijas Vèstnesis, No. 201, 10.10.2017.

9. Judgement of the Constitutional Court of the Republic of Latvia of 25 March 2015 in case No. 2014-11-0103. Available at: http://www.satv.tiesa.gov.lv/web/viewer.html?file=/wpcontent/uploads/2014/04/2014-11-0103_Spriedums_ENG.pdf\#search=2014-11-0103 [last viewed October 8, 2019].

10. Judgement of the Constitutional Court of the Republic of Latvia of 9 October 2014 in case No. 2013-19-03. Latvijas Vēstnesis, No. 201 (5261), 10.10.2014.

11. Judgement of the Constitutional Court of the Republic of Latvia of 3 February 2012 in case No. 2011-11-01. Available at: http://www.satv.tiesa.gov.lv/web/viewer.html?file=/ wp-content/uploads/2011/05/2011-11-01_Spriedums_ENG.pdf\#search=2011-11-01 [last viewed October 8, 2019].

12. Judgement of the Constitutional Court of the Republic of Latvia of 19 December 2011 in case No. 2011-03-01. Available at: http://www.satv.tiesa.gov.lv/web/viewer.html?file=/ wp-content/uploads/2011/02/2011-03-01_Spriedums_ENG.pdf\#search=2011-03-01 [last viewed October 11, 2019]. 
13. Judgement of the Constitutional Court of the Republic of Latvia of 3 May 2011 in case No. 2010-54-03. Latvijas Vēstnesis, No. 70 (4468), 06.05.2011.

14. Judgement of the Constitutional Court of the Republic of Latvia of 24 February 2011 in case No. 2010-48-03. Available at: http://www.satv.tiesa.gov.lv/web/viewer.html?file=/ wp-content/uploads/2010/07/2010-48-03_Spriedums_ENG.pdf\#search=2010-48-03 [last viewed July 16, 2019].

15. Judgement of the Constitutional Court of the Republic of Latvia of 15 March 2010 in case No. 2009-44-01. Available at: http://www.satv.tiesa.gov.lv/web/viewer.html?file=/ wp-content/uploads/2009/07/2009-44-01_Spriedums_ENG.pdf\#search=2009-44-01 [last viewed October 11, 2019].

16. Judgement of the Constitutional Court of the Republic of Latvia of 21 December 2009 in case No. 2009-43-01. Available at: http://www.satv.tiesa.gov.lv/web/viewer.html?file=/ wp-content/uploads/2009/07/2009-43-01_Spriedums_ENG.pdf\#search=2009-43-01［last viewed October 11,2019].

17. Judgement of the Constitutional Court of the Republic of Latvia of 19 November 2009 in case No. 2009-09-03. Latvijas Vēstnesis, No. 184 (4170), 24.11.2009.

18. Judgement of the Constitutional Court of the Republic of Latvia of 24 September 2008 in case No. 2008-03-03. Latvijas Vèstnesis, No. 151 (3935), 30.09.2008.

19. Judgement of the Constitutional Court of the Republic of Latvia of 17 January 2008 in case No. 2007-11-03. Available at: http://www.satv.tiesa.gov.lv/web/viewer.html?file=/ wp-content/uploads/2007/05/2007-11-03_Spriedums_ENG.pdf\#search=2007-11-03 [last viewed October 10, 2019].

20. Judgement of the Constitutional Court of the Republic of Latvia of 25 October 2004 in case No. 2004-03-01. Available at: http://www.satv.tiesa.gov.lv/web/viewer.html?file=/ wp-content/uploads/2004/04/2004-03-01_Spriedums_ENG.pdf\#search=2004-03-01［last viewed October 5, 2019].

21. Judgement of the Constitutional Court of the Republic of Latvia of 30 January 2004 in case No. 2003-20-01. Available at: http://www.satv.tiesa.gov.lv/web/viewer.html?file=/ wp-content/uploads/2003/09/2003-20-01_Spriedums_ENG.pdf\#search=2003-20-01 [last viewed October 11, 2019].

22. Dissenting opinion of the Judge of the Constitutional Court of the Republic of Latvia Daiga Rezevska in case No. 2016-14-01. Latvijas Vèstnesis, No. 251 (6078), 18.12.2017.

23. Judgement of the Supreme Court of the Republic of Latvia on 14 December 2015 in case No. A420445113. Available at: https://manas.tiesas.lv/eTiesasMvc/nolemumi [last viewed October 10, 2019].

24. Judgement of the Supreme Court of the Republic of Latvia on 2 October 2014 in case No. A420401913. Available at: https://manas.tiesas.lv/eTiesasMvc/nolemumi [last viewed October 10, 2019].

25. Judgement of Regional Administrative Court of 30 August 2018 in case No. A43007918. Available at: https://manas.tiesas.lv/eTiesasMvc/nolemumi [last viewed October 7, 2019].

26. Judgement of Regional Administrative Court on 14 June 2018 in case No. A420511213. Available at: https://manas.tiesas.lv/eTiesasMvc/nolemumi [last viewed October 11, 2019].

27. Judgement of Regional Administrative Court of 26 April 2018 in case No. A420296416 para 3. 27. Available at: https://manas.tiesas.lv/eTiesasMvc/nolemumi [last viewed October 4, 2019]. 
28. Judgement of Riga Regional Court of 23 November 2016 in case No. C30692915. Available at: https://manas.tiesas.lv/eTiesasMvc/nolemumi [last viewed October 10, 2019].

\section{Other sources}

1. National Development Plan of Latvia for 2014-2020. Available at: https://www.pkc.gov.lv/ sites/default/files/inline-files/NDP2020\%20English\%20Final___ 1.pdf [last viewed October 5, 2019].

2. Sustainable Development Goals. Available at: https://www.un.org/sustainabledevelopment/ sustainable-development-goals/ [last viewed July 7, 2019].

3. Sustainable Development Strategy of Latvia until 2030. Available at: http://varam.gov.lv/lat/ $\mathrm{pol} / \mathrm{ppd} /$ ?doc $=13857$ [last viewed October 5, 2019], para. 8.

4. Swedbank's Sustainability Indicators: towards the 2030 Agenda. Available at: https://www. swedbank-research.com/english/macro_focus/2018/january/sustainability_indicators 2018-01-23.pdf [last viewed July 16, 2019].

5. United Nations Conference on Environment \& Development Rio de Janerio, Brazil, 3 to 14 June 1992 AGENDA 21. Available at: https://sustainabledevelopment.un.org/content/ documents/Agenda21.pdf [last viewed July 20, 2019].

6. Report of the World Commission on Environment and Development: Our Common Future. Available at: https://www.are.admin.ch/are/en/home/sustainable-development/ international-cooperation/2030agenda/un-_-milestones-in-sustainable-development/1987-brundtland-report.html [last viewed July $7, \overline{2019}$ ]. 